\title{
3D Spherical Harmonics Deformation Visualization of Intraoperative Organ
}

\author{
${ }^{1}$ Greeshma Jacob, ${ }^{2}$ Reshma V. K \\ ${ }^{I}$ MTECH Computer Science and Engineering, Nehru College of Engineering \& Research Centre, Ottapalam, \\ Palakad, Kerala, India \\ ${ }^{2}$ Assistant Professor, Department of Computer Science and Engineering, Nehru College of Engineering \& \\ Research Centre, Ottapalam, Palakad, Kerala, India
}

\begin{abstract}
This paper gives a literature review on the recent experiments on real time $3 D$ visualization of intraoperative organ deformations. Restricted visualization is major challenge in minimal invasive surgery (MIS). For MIS procedures to be safe clear visualization of the surgical scene is required. This can be done based on limited field-of-view and a pre-operative image. This paper presents a review on various visualization techniques emerged recently. The survey is represented in tabular form for quick reference.
\end{abstract}

Index Terms-Deformations, minimal invasive surgery (MIS), surface reconstruction.

I. Introduction

Medical imaging is nowadays gaining lot of importance and wide range of applications. In MIS procedures, it plays a very important role. It guides the surgeon and helps them by identifying the anatomy and pathology. However, the currently using image guided systems have various disadvantages. The important one is restricted visualization of the surgical field from limited access ports. Only critical informations are provided by pre-operative magnetic resonance imaging or computed tomography.

Many techniques are currently used for medical imaging for helping the surgeons. 3D echocardiography is used to get 3D ultrasound images of heart. This technique has been widely useful in cardiac disease diagnosis. Real time 3D systems are also being improving and are gaining importance. But sometimes the accuracy of the results is not so good.

Intraoperative MRI is the next promising and developing image guidance tool for surgeons. It is also experimenting in 3D visualizations. Intraoperative MRI at magnetic flux 3Tesla is also been used. Laparoscopic radiofrequency ablation is another diagnostic tool for liver tumors especially. Lesions or tumors are diagnosed and ablated. Magneto optic tracking transducers are also being used in laparoscopic augmentation. Intraoperative organs geometry is studied and fast recovery of its shape is also done, which helps the surgeons during the surgery.

Navigation in endoscopic soft tissue surgery is done using computer aided systems. Localization and targeting of anatomical structures are very precisely obtained with computer assisted surgery. This is used for organs not performing periodic motions.

4D MR imaging technique also called adaptive 4-D scan aims real time 3D visualization of cyclically moving organs. In this technique a series of volumetric 3D images are collected. A navigator-echo-based real time tracking device is used for this purpose

In this paper a new approach for real time 3D visualization is proposed. Thus we get the 3D image of intra operative organs deformations. It uses spherical harmonics for the setting up of dictionary structured images. Currently no systems provide 3D and real time visuals simultaneously.

\section{Techniques Used For Real Time 3d Visualization of Intraoperative Organ Deformations 3D Echocardiography \\ Earlier 3D anatomy was reconstructed from a series of parallel scans of the human anatomy. This was} done using transducers, and tracked a sequence of 2D echocardiograms. These data is recorded then aligned and then reconstructed. Later real time 3D echocardiographic scanners are introduced. They got evolved very quickly due to its image quality, precision and its capability to expand.

The technique used by real time 3D systems is with matrix-array transducer technology which utilizes a number of imaging elements. Thus it provides improved resolution. But a disadvantage of this technique is that it's difficult to manipulate the transducer. Also some times the quality of the result isn't accurate. 


\section{Intraoperative MRI}

MRI is widely used in neurosurgery as image guidance tool. It uses same modality for localization during surgery. MRI systems are costly and they also lack clear definition of requirements for different systems. In case of MRI it is not still sure whether it can be used for tumor resection control only. It is also unknown whether it is applicable for any neurosurgical procedures.

Due to the introduction of MRI now accurate localization and targeting is possible. For neuro navigation frequent image updates are done. The demerits of this technique are that the impact on neurological practice is not fully yet recognized.

\section{Intraoperative MRI at $3 T$}

The basic need of this technique is to maintain a normal clinic and research activity of magnetic resonance room. Then when the neurosurgeon needs an IoMR procedure it is switched to surgical modality. For achieving this some technical changes have to be done to the OR an MR room. This is done at the magnetic flux 3Tesla.

At earlier stages some technical errors were raised. The cost of MR-OR suite is low compared to surgical MR suites. Also the time needed for IoMRI in MR suites is quite lengthy.

\section{Laparoscopic Radiofrequency Ablation of Liver Tumors}

Laparoscopy is a good diagnostic tool used frequently now days. Exploratory laparoscopy, laparoscopic ultrasound (LUS), and ultrasound-guided biopsy are the assessing techniques used before liver resections. All these are used to diagnose liver lesions. LUS can be used to find lesions of size less than $2 \mathrm{~cm}$ in diameter. This laparoscopic approach is safe for tumor treatments because it possible to visualize directly and control the bleedings from the lesions.

Some lesions may be deep and sometimes not clearly visualized. Then LFRA can be successfully used at these times. LFRA is the first choice if the lesion size is large or in cases of multiple liver tumors.

\section{Magneto-Optic Tracking of a Flexible Laparoscopic Ultrasound Transducer for Laparoscope Augmentation}

Laparoscopic ultrasonography(LUS) is very commonly used for abdominal surgery nowdays. They are applied on liver, bilary tract and pancreas. It supports the surgeons in cancer staging, radio frequency ablations and such procedures. In this a number of tracking errors can be raised. They depend on the operation room setup and instrumentation. For removing the errors several techniques are planned. For this the user needs a set of well distributed measurements within electromagnetic telemetry (EMT) volume.

A smooth visualization is obtained without lag. For that a time stamp is given to all data and brought into same time frame. One problem in this magneto-optic tracking is the accuracy of electromagnetic tracking system. It requires lots of improvements.

\section{Navigation in Endoscopic Soft Tissue Surgery}

Computer assisted navigation systems have acquired great importance in surgical interventions on rigid anatomy. Localization and targeting of anatomical structures are very precisely obtained with computer assisted surgery. This is used for organs not performing periodic motions. It's applicable for abdominal surgery and thoracic surgery. Computer assisted surgery includes surgical devices, surgical robots, surgical navigation, surgical tele- assistance and such techniques which runs with the aid of a computer system.

Eventhough endoscopy for abdominal and thoracic surgery is not so emerging. They have limitations for perception at the time of surgery. They have little tactile feedback, limited mobility and so on.

\section{New 4-D Imaging for Real-Time Intraoperative MRI: Adaptive 4D}

4D MR imaging technique is also called adaptive 4-D scan. Its aim is real time 3D visualization of organ motions. In this technique a series of volumetric 3D images are collected. This is applicable for cyclically moving organs. A navigator-echo-based real time tracking device is used for this purpose.

In respiratory phase, during the surgery it is monitored in real-time. The 3D image is extracted which represents the current state of target organ. The drawback of this method is that the target causes serious artifact on a MR image. So it's difficult for the physician to differentiate lesion and make accurate decision.

\section{Radiofrequency ablation of Liver Tumors}

Radiofrequency ablation (RFA) is a major tool for treatment of non resectable primary and secondary liver tumors. Its advantages are safety and feasibility in treating liver tumors. Eventhough this has adverse effects such as biliary tract damage, liver failure and local recurrence.

RFA is becoming promising. But they have some difficult tasks like incomplete ablation of liver tumors. This is because of insufficient technology for ablation needles, large tumor masses and ablation of tumors close to 
organs which are sensitive to heat. Anyhow RFA is widely used for primary liver tumors because of its ease and safety properties. Its efficiency is good compared to open surgery.

\section{Intraoperative Fast 3D Shape Recovery of Abdominal Organs in Laproscopy}

In computer aided surgery an important key is intraoperative geometric measurements. Geometric information helps in visualization techniques. The laser-scan endoscope system is an example. It acquires the area in laparoscopy and visualizes in little time. Thus this technique provides high speed 3D geometric visualization.In short this 3D shape of the internal anatomy enables the surgeon correct localization and targeting. But real time visualization is not possible here.

\section{D Spherical Harmonics Deformation Visualization}

In this paper a new approach for real time 3D visualization is introduced. This technique uses spherical harmonics and sparse signal representations for creating a training set. There are also testing sets. Only patches of images are got during minimum invasive surgery. In this approach from these patches we are reconstructing the whole 3D model. Thus it becomes easier for the surgeons. The main advantage of this approach compared to others is that, currently no other system provides high resolution, real time and 3D images simultaneously.

\begin{tabular}{|c|c|c|c|c|}
\hline $\begin{array}{l}\text { Various Imaging } \\
\text { and Visualization } \\
\text { approaches }\end{array}$ & Techniques used & Features & Advantages & Disadvantages \\
\hline $\begin{array}{l}\text { 3D } \\
\text { Echocardiography }\end{array}$ & $\begin{array}{l}-\bullet \quad \text { Display } \\
\text { ultrasound images in } \\
\text { 3D format, } \\
-\quad 3 D \text { data set } \\
\text { reconstructed from } \\
\text { 2D series of images }\end{array}$ & $\begin{array}{l}\text { - Limited } \\
\text { image quality and } \\
\text { computational } \\
\text { power needed for } \\
\text { storage and } \\
\text { reconstruction } \\
\text { - Improve } \\
\text { and expand } \\
\text { diagnostic } \\
\text { capabilities of } \\
\text { cardiac ultrasound. }\end{array}$ & $\begin{array}{l}\text { - Improve and } \\
\text { expand diagnostic } \\
\text { capabilities of cardiac } \\
\text { ultrasound. } \\
\text { - 3D } \\
\text { echocardiography, } \\
\text { examine the evidence } \\
\text { for its use in various } \\
\text { clinical situations }\end{array}$ & $\begin{array}{l}\text { - Cartesian } \\
\text { coordinate system } \\
\text { including the relative } \\
\text { bulk of the acoustic } \\
\text { spatial locators, } \\
\text { makes transducer } \\
\text { manipulation } \\
\text { difficult } \\
\text { path between the } \\
\text { acoustic locators and } \\
\text { the transmitter } \\
\text { doesn't accurate } \\
\text { result in the quality } \\
\text { of the result. }\end{array}$ \\
\hline $\begin{array}{l}\text { Future perspectives } \\
\text { for intraoperative } \\
\text { MRI }\end{array}$ & $\begin{array}{l}\text { - Magnetic } \\
\text { resonance }\end{array}$ & $\begin{array}{lr} & \text { Valuable } \\
\text { image } & \text { guidance } \\
\text { tool } & \text { for } \\
\text { neurosurgery } \\
\text { - } & \text { Expanded } \\
\text { operational } & \text { field } \\
\text { view from } & \text { 2D to } \\
\text { 3D } & \end{array}$ & $\begin{array}{l}\text { - Augmented } \\
\text { the surgeon's eye via a } \\
\text { more effective tissue } \\
\text { definition than direct } \\
\text { visual examination } \\
\text { i Frequent } \\
\text { image updates for } \\
\text { neuronavigation }\end{array}$ & $\begin{array}{l}- \\
\text { clear definition } \\
\text { - } \quad \text { High cost } \\
\text { impact on everyday } \\
\text { neurosurgical } \\
\text { practice is not yet } \\
\text { fully recognized }\end{array}$ \\
\hline $\begin{array}{l}\text { Intra-operative } \\
\text { MRI at 3T }\end{array}$ & $\begin{array}{l}\text { Magnetic } \\
\text { flux of 3Tesla used }\end{array}$ & $\begin{array}{l}\text { - } \\
\text { needed to perform } \\
\text { IoMRI at 3T } \\
\text { p Technical } \\
\text { problems } \\
\text { encountered }\end{array}$ & $\begin{array}{l}\text { - Cost } \\
\text { effectiveness of MR- } \\
\text { OR suite is obviously } \\
\text { lower when compared } \\
\text { to only surgical use MR } \\
\text { suites. } \\
\text { p Technical } \\
\text { problems countered } \\
\text { were all solved in real } \\
\text { time }\end{array}$ & \begin{tabular}{lc} 
& \multicolumn{2}{c}{ Time } \\
needed to perform \\
IoMRI high in \\
existing system
\end{tabular} \\
\hline $\begin{array}{l}\text { Laparoscopic } \\
\text { Radiofrequency } \\
\text { Ablation of Liver } \\
\text { Tumors }\end{array}$ & \begin{tabular}{llr}
$\bullet$ & \multicolumn{2}{c}{ Reliable } \\
diagnostic & tool \\
mainly in liver \\
tumors \\
- In \\
association with intra
\end{tabular} & $\begin{array}{l}\text { Direct } \\
\text { visualization and } \\
\text { active protection }\end{array}$ & 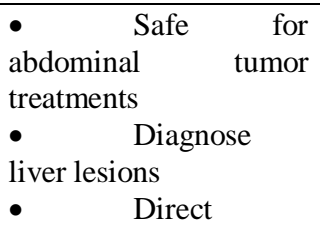 & \begin{tabular}{lr} 
& \multicolumn{2}{c}{ Majority of } \\
the reports about \\
RFA refer r to \\
malignant \\
tumors liver \\
$\begin{array}{rrr} & \text { RFA } & \\
& \text { must }\end{array}$
\end{tabular} \\
\hline
\end{tabular}




\begin{tabular}{|c|c|c|c|c|}
\hline & $\begin{array}{l}\text { operative ultrasound } \\
\text { examination }\end{array}$ & & $\begin{array}{l}\text { visualization and active } \\
\text { protection }\end{array}$ & $\begin{array}{l}\text { be integrated in a } \\
\text { complex multimodal } \\
\text { treatment for patient } \\
\text { with liver tumors. }\end{array}$ \\
\hline $\begin{array}{l}\text { Magneto-Optic } \\
\text { Tracking of a } \\
\text { Flexible } \\
\text { Laparoscopic } \\
\text { Ultrasound } \\
\text { Transducer for } \\
\text { Laparoscope } \\
\text { Augmentation }\end{array}$ & $\begin{array}{lc} & \text { Laproscopi } \\
\text { c ultrasonography } \\
\bullet \quad \text { EMT } \\
\text { systems }\end{array}$ & $\begin{array}{l}- \\
\text { on areas include } \\
\text { liver, biliary tract } \\
\text { and pancreas }\end{array}$ & $\begin{array}{l}\text { - } \\
\text { visualization } \quad \text { without } \\
\text { lag }\end{array}$ & $\begin{array}{l}\text { - Accuracy } \\
\text { of current } \\
\text { electromagnetic } \\
\text { tracking systems has } \\
\text { still need a lot of } \\
\text { improvement }\end{array}$ \\
\hline $\begin{array}{l}\text { Navigation in } \\
\text { Endoscopic Soft } \\
\text { Tissue Surgery - } \\
\text { Perspectives and } \\
\text { Limitations }\end{array}$ & $\begin{array}{l}\bullet \quad \text { Supported } \\
\text { by computer assisted } \\
\text { navigation systems }\end{array}$ & $\begin{array}{lr}- & \text { Localizati } \\
\text { on } & \text { and } \\
\text { visualization } & \text { of } \\
\text { tumors and risk } \\
\text { structures }\end{array}$ & $\begin{array}{l}\text { - Computer } \\
\text { assistance systems can } \\
\text { improve the surgeons } \\
\text { knowledge } \\
\text { Endoscopic thoracic } \\
\text { and abdominal surgery }\end{array}$ & $\begin{array}{l}- \text { Limitations } \\
\text { of perception during } \\
\text { endoscopic surgery } \\
\text { - Little } \\
\text { tactile feedback, } \\
\text { limited mobility and } \\
\text { handling of } \\
\text { instruments }\end{array}$ \\
\hline $\begin{array}{l}\text { New 4-D Imaging } \\
\text { for } \quad \text { Real-Time } \\
\text { Intraoperative MRI: } \\
\text { Adaptive 4-D Scan }\end{array}$ & $\begin{array}{l}\text { - Navigator } \\
\text { gating technique }\end{array}$ & $\begin{array}{l}\text { Based on } \\
\text { 2D and 3D images } \\
-\quad \text { Promisin } \\
\text { g tool for surgical } \\
\text { guidance }\end{array}$ & $\begin{array}{l}\text { - 3D images of } \\
\text { the liver reconstructed } \\
\text { for } \quad \text { complete } \\
\text { respiratory cycle by } \\
\text { retrospective stacking } \\
\text { of dynamic 2D images }\end{array}$ & $\begin{array}{l}\text { - } \\
\text { causes } \\
\text { artifact on a } \\
\text { image } \\
\text { ferious } \\
\text { for physicians to } \\
\text { discriminate the } \\
\text { lesion and make } \\
\text { accurate decision } \\
\text { difficult. }\end{array}$ \\
\hline $\begin{array}{l}\text { Radiofrequency } \\
\text { ablation of liver } \\
\text { tumors: Actual } \\
\text { limitations and } \\
\text { potential solutions } \\
\text { in the future }\end{array}$ & $\begin{array}{l}\text { - Therapeutic } \\
\text { al tool for treatment } \\
\text { of primary and } \\
\text { secondary } \\
\text { tumors }\end{array}$ & $\begin{array}{l}\text { - } \\
\text { technique } \\
\text { ablation of liver } \\
\text { tumors }\end{array}$ & $\begin{array}{l}\text { - RFA } \\
\text { investigates the } \\
\text { ablation of small } \\
\text { hepatocellular } \\
\text { carcinomas (HCC) in } \\
\text { patients with liver } \\
\text { cirrhosis standard } \\
\text { technique of ablation of } \\
\text { liver tumors } \\
\text { - evaluate the } \\
\text { right indications for the } \\
\text { best possible benefits } \\
\text { for patients }\end{array}$ & $\begin{array}{l}\text { Severe } \\
\text { adverse effects of } \\
\text { RFA of liver tumors } \\
\text { have been critically } \\
\text { investigated but still } \\
\text { becomes less result } \\
\text { getting injured when } \\
\text { not protected } \\
\text { simultaneously with } \\
\text { intraductal cooling }\end{array}$ \\
\hline $\begin{array}{lr}\text { Intraoperative } & \text { Fast } \\
\text { 3D Shape Recovery } \\
\text { of Abdominal } \\
\text { Organs } \\
\text { Laparoscopy }\end{array}$ & $\begin{array}{l}- \text { Laser scan } \\
\text { laproscopy }\end{array}$ & $\begin{array}{l}-\quad \text { Provide } \\
\text { an intuitive } \\
\text { orientation under } \\
\text { laparoscopic } \\
\text { surgery } \\
\end{array}$ & $\begin{array}{l}\text { - High-speed } \\
\text { 3D geometric } \\
\text { visualization }\end{array}$ & 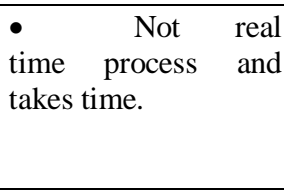 \\
\hline $\begin{array}{l}\text { Real time } 3 \mathrm{D} \\
\text { visualization of } \\
\text { organ deformations } \\
\text { using structured } \\
\text { dictionary }\end{array}$ & 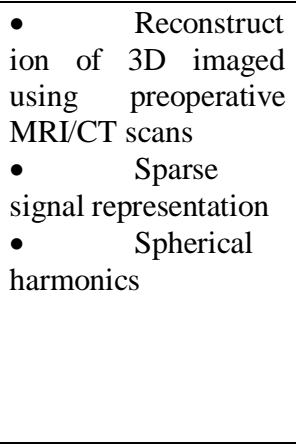 & $\begin{array}{l}\text { - Reconstr } \\
\text { uction algorithm } \\
\text { can keep up with } \\
\text { scanning speed. } \\
\text { - Solves } \\
\text { problem } \\
\text { restricted of } \\
\text { visualization } \\
\text { - High } \\
\text { resolution 3D real } \\
\text { time visualization } \\
\text { provided }\end{array}$ & $\begin{array}{l}\text { - } \\
\text { resolution images } \\
\text { - } \quad \text { Real time } \\
\text { surface } \\
\text { sampling achieves high } \\
\text { accuracy } \\
\text { - } \quad \text { Helps } \\
\text { accurate localization } \\
\text { and targeting }\end{array}$ & $\begin{array}{lr}\bullet & \text { No } \\
\text { disadvantages }\end{array}$ \\
\hline
\end{tabular}

Table1: Comparison table on literature survey

III. Conclusion

The paper presents a novel approach for real time 3D visualization of organ deformations using a 
single preoperative MRI scan and optical patch imaging from a limited field-of-view. Then reconstructs complete deformable shapes of an organ in real time using limited surface samples based on a structured dictionary. Reconstruction algorithms can be used. The proposed approach involves sparse surface representation and surface recovery from sparse samples. Thus the proposed approach aims at better 3D real time visualization of intraoperative organ deformations using structured dictionary.

\section{References}

[1]. Judy Hung, MD et al (2007) "3D Echocardiography: Review of the Current Status and Future Directions" in Journal of the American Society of Echocardiography, pp. 213-233.

[2]. F.A.Jolesz, (2005) "Future perspectives for intraoperative MRI," Neurosurg. Clin. N. Am., vol. 16, no. 1, pp. 201-213.

[3]. C. L. Truwit and W. A. Hall, "Intraoperative magnetic resonance imaging-guided neurosurgery at 3-T," Neurosurgery, vol. 58, no. 4, pp. 338-345, 2006.

[4]. M. Feuerstein, T. Reichl, J. Vogel, J. Traub, and N. Navab, "Magnetooptical tracking of flexible laparoscopic ultrasound: Modelbased online detection and correction of magnetic tracking errors," IEEE Trans.Med. Imag., vol. 28, no. 6, pp. 951-967, Jun. 2009.

[5]. J. Tokuda et al., "New 4-D imaging for real-time intraoperative MRI: Adaptive 4-D scan," in Int. Conf. Med. Image Computing Computer-Assist. Intervent., 2006, pp. 454-61.

[6]. "Radiofrequency ablation of liver tumors: Actual limitations and potential solutions in the future" by Beat M Künzli, Paolo Abitabile, Christoph A Maurer

[7]. "Laproscopic Radiofrequency Ablation of Liver Tumors" by Mirela Patricia Sîrb Boeti, Răzvan Grigorie and Irinel Popescu

[8]. "Intraoperative Fast 3D Shape Recovery of Abdominal Organs in Laparoscopy" by Mitsuhiro Hayashibe, Naoki Suzuki,Asaki Hattori, and Yoshihiko Nakamura

[9]. Dan Wang, Ahmed H.Tewfik (2012) "Real Time 3D visualization of IntraOperative Organ Deformations Using Structured Dictionary" in IEEE Transactions on Medical Imaging, vol. 31, no. 4, pp. 924-937. 